\title{
Stem and crown gall disease caused by Agrobacterium tumefaciens on Golden Euonymus in Iran
}

\author{
Aram Ganjeh $^{1} \cdot$ Heshmatollah Rahimian ${ }^{1} \cdot$ Valiollah Babaeizad $^{1} \cdot$ Esmaeil Basavand $^{2}$ (D)
}

Received: 3 April 2020 / Accepted: 9 June 2020 / Published online: 24 June 2020

(C) Società Italiana di Patologia Vegetale (S.I.Pa.V.) 2020

Keywords $16 \mathrm{~s}$ rDNA $\cdot$ MLSA $\cdot \operatorname{VirD}$

In April 2016, samples of the stem and crown gall of Golden Euonymus with small to over $12 \mathrm{~cm}$ in diameter galls were collected from nurseries in the Mazandaran province, Iran (in total 10 symptomatic plants from 4 nurseries). From young galls, single colonies similar to Agrobacterium were isolated using conventional bacteriological methods (Basavand et al. 2020). Pathogenicity of 10 isolates with type strain was confirmed by stab inoculation of 11 tomato seedlings per isolate with a bacterial suspension of $c a .1 \times 10^{7} \mathrm{CFU} \mathrm{ml}{ }^{-1}$ and formation of galls on its stems in the following four weeks after inoculation. To fulfill Koch's postulates, re-isolation resulted on $\mathrm{PDA}+\mathrm{CaCO}_{3}$ medium and re-isolates were identified using standard bacteriological methods. Isolates (fifteen in total) were Gram- negative, catalase and oxidase positive, motile and aerobic. All isolates grew on $2 \% \mathrm{NaCl}$ and at $35^{\circ} \mathrm{C}$, produced levan and urease and hydrolyzed Tween 80 . They were negative in tests for production of fluorescent pigment, lecithinase, nitrate reduction, indole production, and hydrolysis of gelatin and starch. All isolates were capable of producing $3^{\prime}$-ketolactose and a pellicle on ferric ammonium citrate. They used dulcitol, arabitol, fructose, sorbitol, cellobiose, glycerol, lactate, xylitol and D-tartrate as source of carbon for growth. None of the isolates utilized $\beta$-alanine, valine,

Esmaeil Basavand

e.basavand@vru.ac.ir

1 Department of Plant Pathology, Sari Agricultural Sciences and Natural Resources University, Sari, Iran

2 Department of Plant Pathology, Vali-e-Asr University of Rafsanjan, Rafsanjan, Iran erythritol, L- tartrate, tyrosine, citrate or malonate. In all the identification tests, the type strain of A. tumefaciens (ICMP 5856) isolated from Malus was used as positive control. Results of biochemical assays were supported using the specific pair primer virD2A/virD2C in MLSA (Bini et al. 2008), and the $\operatorname{Vir} D$ gene 224 bp fragment was amplified in 15 representative isolates by PCR. Moreover, the nucleotide sequence of the partial 16S ribosomal RNA of one representative isolate (Y15) using primer pairs FD1/RD1 (Weisburg et al. 1991) was amplified and sequenced. The sequence (accession No. LC143377.1) was highly (99\%) similar to its corresponding sequence of $A$. tumefaciens isolates existing in GenBank. This is the first report of occurrence of stem and crown gall caused by A. tumefaciens on Golden Euyonymus in Iran.

Acknowledgments This research was supported by, the Vice Chancellor of Research and Technology at the Sari Agricultural Sciences and Natural Resources University, Iran.

\section{References}

Basavand E, Khodaygan P, Rahimian H, Solhizadeh A (2020) Bacterial leaf spot on Convolvulus arvensis caused by Pseudomonas sp. Indian Phytopathology 73:175-176

Bini F, Kuczmog A, Putnoky P, Otten L, Bazzi C, Burr TJ, Szegedi E (2008) Novel pathogen-specific primers for the detection of Agrobacterium vitis and Agrobacterium tumefaciens. Vitis 47: 181-189

Weisburg WG, Barns SM, Pelletier DA, Lane DJ (1991) 16S ribosomal DNA amplification for phylogenetic study. J Bacteriol 173:697-703

Publisher's note Springer Nature remains neutral with regard to jurisdictional claims in published maps and institutional affiliations. 